\title{
Pers di Indonesia, Malaysia dan Thailand: Sama-sama Bebas tetapi Berbeda
}

\author{
https://doi.org/10.25008/caraka.v2i2.64
}

Haresti Asysy Amrihani

Universitas Airlangga - Surabaya

\begin{abstract}
Every country has regulations in regulating press freedom, including Indonesia, Malaysia, and Thailand. Freedom of the press in Indonesia is guaranteed by the 1945 Constitution of the Republic of Indonesia article and the law No. 40 of 1999 concerning the Press. In Malaysia, freedom of the press is regulated in Article 10 of the Federal Constitution, and in Thailand it is regulated in the media regulation constitution made by the National Reform plans. This study aims to understand the press freedom in the three ASEAN member countries. The paradigm used is constructivist with a qualitative descriptive approach. The method used is a literature study. Data were obtained from secondary sources such as from various national and international journals, books, articles, news, and other supporting documents. The research finding is, from the three countries, press freedom in Indonesia is relatively better than Malaysia and Thailand. Indonesia ranks 113 in the worldwide press freedom index, while Malaysia is at 119, and Thailand is at 137.
\end{abstract}

Keyword: press freedom; press regulation; different but free; liberal press; democratic country

\section{ABSTRAK}

Setiap negara memiliki regulasi dalam mengatur kebebasan pers, termasuk Indonesia, Malaysia, dan Thailand. Kebebasan pers di Indonesia dijamin oleh Undang-undang Dasar 1945 Pasal dan Undang Undang Nomor No 40 Tahun 1999 tentang Pers. Di Malaysia, kebebasan pers diatur dalam Kontitusi Federal Pasal 10, dan di Thailand diatur dalam undang-undang pengaturan media yang dibuat oleh Majelis Persiapan Reformasi Nasional. Studi ini bertujuan untuk memahami kebebasan pers di tiga negara anggota ASEAN itu. Paradigma yang digunakan adalah konstruktivis dengan pendekatan deskriptif kualitatif. Metode yang digunakan adalah studi literatur. Data diperoleh dari sumber sekundea seperti dari berbagai jurnal nasional dan internasional, buku, artikel, berita, maupun dokumen pendukung lainnya. Temuan penelitian adalah, dari ketiga negara tersebut, kebebasan pers di Indonesia relative lebih baik daripada Malaysia, dan Thailad. Indonesia menempati peringkat 113 dalam indeks kebebasan pers dari seluruh dunia, sedangkan Malaysia di urutan 119, dan Thailand di urutan 137.

Kata kunci: kebebasan pers; regulasi pers; beda tetapi bebas; pers liberal; negara demokratis

Haresti Asysys Amrihani's email: haresti.asysy.amrihani-2021@fisip.unair.ac.id

Para penulis menyatakan tidak mempunyai konflik kepentingan dalam penelitian dan penerbitan publikasi ini.

Copyright (C) 2021 (Haresti Asysy Amrihani).

Licensed under the Creative Commons Attribution-NonCommercial-ShareAlike 4.0 (CC BY-SA 4.0)Available at http://caraka.web.id

Submitted: 12 Jan 2022, Revised: 17 Jan 2022, Accepted: 25 Jan 2022 


\section{PENDAHULUAN}

Kemerdekaan pers di Indonesia saat ini berbeda dengan masa Orde Baru (Lesmana, 2005). Di era orde Baru, kebebasan pers dibatasi pemerintah sehingga pers berada di bawah kekuasaan pemerintah. Kontrol pemerintah terhadap media massa pada saat itu sangat dominan, dan semua keran kebebasan pers dikunci rapat. Akibatnya, pers tidak dapat memberitakan sesuatu secara akurat. Bila melanggar, pemerintah membredelnya, seperti dialami majalah Tempo, Detik, dan Editor tahun 1997 (Poti, 2011).

Berita menyangkut keluarga Presiden Soeharto juga tabu disiarkan. Ketika Tommy Soeharto mengalami kecelakaan saat latihan di Sirkuit Sentul, pers tidak boleh mempublikasikannya karena berita tersebut dikhawatirkan dapat menjelekkan martabat keluarga kepala negara. Berita semacam ini sangatlah sensitif. Perilaku bisnis anak-anak Soeharto, maupun bisnis para petinggi pemerintah, ketika itu untouchable. Pers yang bandel dan tidak mematuhi "imbauan", sudah pasti terancam bredel (Lesmana, 2005).

Setelah Orde Baru tumbang, kebebasan pers mulai bersinar di Indonesia yang dikuatkan dengan terbitnya Undang Undang Nomor 40 Tahun 1999 tentagn Pers. Prinsip undangundang itu adalah: kemerdekaan pers milik rakyat dan pers menjalankan amanah kemerdekaan pers dengan prinsip keseimbangan (Sukardi, 2012). Pers diberikan hak-hak yang memadai untuk menjalankan kemerdekaannya.

Pasal 4 ayat 2 Undang Undang Nomor 40 Tahun 1999 tentang Pers dengan tegas menyatakan: "Terhadap pers nasional tidak dikenakan penyensoran, pembredelan atau pelarangan penyiaran". Ini berarti, penyensoran, pembredelan, atau pelarangan penyiaran tidak berlaku di Indonesia. Siaran yang bukan merupakan bagian dari pelaksanaan kegiatan jurnalistik diatur dalam ketentuan undang-undang yang lain (Dewan Pers, 2021).

Pada era reformasi, peran dan fungsi pers mengalami perkembangan yang signifikan. Tidak ada pemberedelan terhadap pers di Indonesia. Keberanian pers dalam mengkritik penguasa juga menjadi ciri baru dari kebebasan pers Indonesia. Kondisi ini menunjukkan bahwa tidak ada lagi yang ditakuti pers (Martini, 2014). Berbeda halnya dengan Malaysia dan Thailand.

Di Malaysia, kebebasan berpendapat dijamin berdasarkan Konstitusi Federal. Pasal 10 Konstitusi Federal menjamin hak setiap warga negara dalam berekspresi dalam batasan tertentu, dan sesungguhnya tidak ada kekuatan yang menghalangi masyarakat di sana untuk menyuarakan pendapat dan pikirannya. Media massa Malaysia, sejatinya bebas dari sensor. Namun, pasal yang mengakui kebebasan sebagai hak yang melekat pada setiap individu itu, dalam praktiknya takluk pada undang-undang anti penghasutan atau sedition act 1948 yang demikian lentur, layaknya pasal karet yang ditafsirkan penguasa (Shahab, 2018).

Februari 2021 lalu, pengadilan tertinggi Malaysia menjatuhkan sanksi denda 500.000 ringgit atau sekitar 1,74 miliar rupiah kepada portal berita Malaysiakini.com karena lima komentar pembacanya dianggap menghina pengadilan (Nursalikah, 2021). Malaysiakini.com merupakan portal popular di Malaysia yang melaporkan kesalahan elit penguasa. Pemimpin redaksinya, Steven Gan dituduh menghina pengadilan dalam kasus yang diajukan Jaksa Agung Malaysia (VOA, 2021). Denda tersebut lebih dua kali lipat dari tuntutan jaksa. Majelis hakim di Pengadilan Federal memutuskan dengan suara enam banding satu: outlet media bertanggung jawab sepenuhnya atas isi berita mereka, termasuk isi di bagian komentar (Siswanto, 2021).

Tidak jauh berbeda dengan Thailand. Ketika di sana terjadi aksi demonstrasi besar pada Oktober 2020, Pemerintah Thailand berupaya menekan eskalasi demonstrasi dengan berbagai upaya. Salah satunya dengan membatasi aktivitas jurnalistik. Pemerintah Thailand menerbitkan Dekrit Darurat untuk menghentikan aksi unjuk rasa terhadap pemerintah dan kerajaan Thailand. Hal ini memicu amarah dari berbagai media. Mereka menuding hal itu 
sebagai serangan terhadap kebebasan pers yang dilakukan oleh Perdana Menteri Prayuth Chan-ocha (Rizal, 2020).

Klub Koresponden Asing Thailand (FCCT) juga menyatakan keprihantinannya pada ancaman pemerintah yang tidak responsif terhadap kritik. Organisasi media meminta Pemerintah Thailand tidak melanggar kebebasan pers, setelah pemerintah menyensor lima media online karena dituduh melanggar aturan keadaan darurat. The National Press Council of Thailand, the News Broadcasting Council of Thailand, Thai Journalists Association, Thai Broadcast Journalists Association, dan Online News Providers Association and the National Union of Journalists Thailand menentang segala bentuk penindasan kebebasan media oleh pihak manapun. Mereka mendesak pemerintah untuk tidak menyelahgunakan hukum dengan membungkam media dan mengancam media (Idrus, 2020).

Mengacu dari uraian di atas, maka permasalahan dalam artikel ini adalah bagaimana kebebasan pers di Indonesia sebagaimana diamanatkan pada Pasal 4 ayat 2 UU Pers No 40 tahun 1999, dibandingkan dengan pasal tentang kebebasan pers di Malaysia dan Thailand.

Berangkat dari permasalahan tersebut, tujuan dari artikel ini adalah untuk memahami perbedaan kebebasan pers di Indonesia, Malaysia, dan Thailand. Metode yang digunakan pada artikel ini adalah studi literatur atau studi pustaka dari sumber-sumber sekunder yang diperoleh dari surat kabar, jurnal nasional dan internasional, buku, dan dokumen-dokumen pendukung lainnya. Paradigma yang digunakan adalah paradigma konstruktivis dengan pendekatan deskriptif kualitatif dengan peneliti sebagai instrumen utama penelitian.

\section{KERANGKA TEORI}

Pers umumnya tunduk pada sistem pers yang berlaku di mana sistem itu hidup, sementara sistem pers itu sendiri tunduk pada sistem politik pemerintahan yang ada. Bersama dengan lembaga kemasyarakatan lainnya, pers berada dalam keterikatan organisasi yang bernama negara. Oleh karena itu, pers dipengaruhi bahkan ditentukan oleh falsafah dan sistem politik negara di mana pers itu berada. Singkat kata, perkembangan dan pertumbuhan pers tidak dapat dipisahkan dari perkembangan dan pertumbuhan sistem politik di mana pers itu berada, dan merupakan subsistem dari sistem politik yang ada (Suwardi, 1993).

Sistem pers dunia telah dipetakan sebagai hasil kajian Fred S. Siebert, Theodore Peterson, dan Wilbur Schramm dalam buku Empat Teori Pers (1986). Buku tersebut mengkategorikan teori-teori pers di dunia, yaitu: teori pers otoriter, teori pers bebas (liberal), teori pers bertanggungjawab sosial dan teori pers komunis Soviet. Keempat teori pers tersebut mengasumsikan bahwa pers selalu mengambil bentuk dan struktur sosial politik di mana pers tersebut beroperasi (Waluyo, 2018).

Secara garis besar Siebert, Peterson, dan Schramm (1986) membagi pers dalam empat katagori yang disebut sebagai Teori Pers, yakni: (1) pers otoriter; (2) pers bebas; (3) pers dengan tanggung jawab sosial, dan (4) pers komunis Uni Soviet. Meskipun negara Uni Soviet sudah tidak ada, dan paham komunis hanya berlaku di sedikit negara, namun teori pers komunis tetap relevan hingga kini, seperti juga pers otoriter, pers bebas, dan pers dengan tanggung jawab sosial tetap eksis sampai sekarang.

Pers Otoriter. Teori pers otoriter atau otoritarian menyatakan, kebebasan pers sepenuhnya bertujuan untuk mendukung pemeritah yang bersifat otoriter sehingga pemerintah menguasai, dan mengendalikan media massa (Purwanto, 2005). Teori ini merupakan teori pers tertua, berasal dari abad ke-16, dari falsafah kenegaraan yang membela kekuasaan absolut. Penetapan tentang kebenaran dipercayakan kepada penguasa (Waluyo, 2018). Pers harus mendukung kebijakan pemerintah dan mengabdi kepada negara. Para penerbit diawasi melalui izin terbit dan sensor (Siebert, F., Peterson, T., Schramm, W, 1986).

Model komunikasi yang terjadi pada paham otoriterisme adalah komunikasi satu arah. 
Dalam menjalankan tugasnya baik dalam menyampaikan gagasan, pemikiran, dan pesan, kelompok otoritarian hanya mengenal satu bentuk komunikasi yaitu instruksi. Bentuk komunikasi yang persuasif untuk meyakinkan, dinilai menghabiskan waktu dan tidak efisien. Meski kebebasan bersuara dibatasi, namun selama pandangan yang dikemukakan tidak megancam pemerintah, maka hal itu masih diperbolehkan (Triyono, 2013). Teori pers otoriter kini tidak lagi digunakan di negara-negara demokratis, tetapi praktik-praktik otoritarian cenderung mempengaruhi proses demokrasi (Waluyo, 2018).

Pers Liberal/Bebas. Teori pers bebas atau libertarian memandang manusia sebagai makhluk rasional yang dapat membedakan antara yang benar dan salah. Kemudian berkembang pandangan dalam teori ini, pers perlu mengawasi pemerintah. Pers sebagai pilar keempat demokrasi mulai berkembang setelah kekuasaan eksekutif, legislatif, dan yudikatif menjadi umum diterima dalam teori pers libertarian. Oleh karenanya, pers harus bebas dari pengaruh dan kendali pemerintah. Sebagian besar aturan yang ada dalam teori ini hanyalah untuk menciptakan keuntungan berupa materi bagi pemilik modal (Waluyo, 2018).

Ada tiga konsep fundamental dalam kebebasan pers (Baran \& Davis, 2012), yakni (1) Teologi: memberikan forum bagi masyarakat untuk menilai baik dan buruk; (2) Kebebasan individu: kebebasan pers merupakan kebebasan terkuat, setidaknya kebebasan dari elit politik, (3) Kebenaran: kebohongan dan hal yang salah harus dilawan, suatu ggaasan harus dapat diuji.

Pers seharusnya bebas dari pengawasan dan pengaruh pemerintah. Agar kebenaran bisa muncul, semua pendapat harus dapat kesempatan yang sama untuk didengar, harus ada pasar bebas pemikiran dan informasi. Baik kaum minoritas maupun mayoritas, kuat maupun lemah, harus dapat menggunakan pers. Selain memberi hak warga untuk bersuara dan kontrol sosial, pers dalam paham ini bertugas: melayani kehidupan politik, mencari keuntungan, memberi hiburan (Triyono, 2013).

Pers Tanggung Jawab Sosial. Teori pers tanggungjawab sosial menekankan, pers bertanggungjawab pada masyarakat atau kepentingan umum. Undang-undang Nomor 40 tahun 1999 tentang Pers memberi kewenangan kontrol kepada masyarakat (Hutagalung, 2013). Teori ini memiliki asumsi utama yaitu kebebasan, mengandung di dalamnya suatu tanggung jawab yang sepadan (Siebert, F., Peterson, T., Schramm, W, 1986).

Menurut laporan Commision on the Freedom (1949), terdapat lima syarat bagi pers yang bertanggung jawab kepada masyarakat, yaitu: (1) media harus menyajikan berita-berita peristiwa sehari-hari yang dapat dipercaya, lengkap, dan cerdas dalam konteks yang memberikannya makna; (2) media harus berfungsi sebagai forum untuk pertukaran komentar dan kritik; (3) media harus memproyeksikan gambaran yang benar-benar mewakili kelompok konstituen dalam masyarakat; (4) media harus menyajikan dan menjelaskan tujuan dan nilai masyarakat; (5) media harus menyediakan akses penuh terhadap informasi yang tersembunyi.

Teori Pers Komunis Soviet. Teori pers ini dikembangkan pada masa komunis atau Nazi yang disebut juga penindasan dari kelompok plural untuk propaganda yang dipusatkan pada budaya politik (Siebert, F., Peterson, T., Schramm, W, 1986). Postulat teori ini antara lain: (1) Media seyogyanya melayani kepentingan dari dan berada di bawah pengendalian kelas pekerja; (2) media seyogyanya tidak dimiliki secara pribadi; (3) media harus melakukan fungsi positif bagi masyarakat dengan sosialisasi terhadap norma yang diinginkan; (4) masyarakat berhak melakukan sensor dan tindakan hukum lainnya untuk mencegah atau menghukum setelah terjadinya peristiwa, publikasi, anti masyarakat; (5) media hendaknya mendukung gerakan progresif di dalam dan luar negeri (Triyono, 2013).

Saat ini teori pers komunis hanya dianut oleh Republik Rakyat China, Korea Utara, dan Kuba, tiga negara yang masih mempertahankan ideologi komunis. Ciri-ciri teori pers ini 
adalah: dihilangkannya motif profit, menomorduakan topik berita, dan mempertahankan status quo bagi penguasa (Waluyo, 2018). Para anggota komunis percaya dengan adanya kontrol yang berlebihan dari media, bisa mendidik masyarakat serta memimpin masyarakat sepeti yang diinginkan, oleh karena itu media harus dikuasai dan dikendalikan (Baran \& Davis, 2012).

Sementara itu, dalam perspektif pers bebas, McQuail menetapkan sejumlah ciri yang melekat yang mencakup (1) publikasi seyogyanya bebas dari penyensoran pendahuluan pihak ketiga; (2) tindakan penerbitan dan pendistribusian media sebaiknya terbuka bagi setiap orang atau kelompok tanpa memerlukan izin atau lisensi yang dikeluarkan oleh penguasa; (3) kecaman terhadap pemerintah, pejabat atau partai politik (yang berbeda dari kecaman terhadap orang-orang secara pribadi atau pengkhianatan dan gangguan kemanan), seyogyanya tidak dapat dipidanakann, bahkan setelah terjadinya persitiwa tersebut; (4) seyogyanya tidak ada kewajiban mempublikasikan segala hal di media massa melalui kekuatan politik maupun kekuasaan modal (McQuail, 2002).

Karakter lain pers bebas adalah publikasi kesalahan dilindungi sama dengan halnya dengan publikasi terhadap kebenaran dalam hal yang berkaitan dengan opini atau keyakinan. Selayaknya tidak ada btasan hukum yang diberlakukan terhadap upaya pengumpulan informasi untuk kepentingan pubikasi. Di samping itu, seyogyanya pemberitaan media massa, tidak ada batasan hukum yang diberlakukan dalam impor, ekspor atau pengiriman dan penerimaan pesan, di seluruh pelosok negeri (McQuail, 2002). Demokratisasi dalam khidupan berbangsa dan bernegara menuntut kebebasan pers dalam pemberitaan. Lepas dari tekanan pihak yang berkuasa secara sosial, budaya, politik, maupun ekonomi (Susanto, 2013).

\section{METODE PENELITIAN}

Penelitian ini merupakan kajian literatur atau kajian kepustakaan. Kajian literatur atau kajian kepustakaan (literature review or literature research) adalah penelitian yang mengkaji, menelaah secara kritis suatu pengetahuan, gagasan, ide, atau temuan yang terdapat dalam suatu literatur dengan berorientasi akademik serta merumuskan dan mengkonstruk kontribusi teoritis dan metodologis untuk suatu topik tertentu (Marzuki, 2005).

Fokus dari kajian literatur adalah menemukan berbagai gagasan, dalil, teori, prinsip atau hukum yang digunakan untuk menelaah serta menganalisis sebagai upaya untuk menjawab pertanyaan penelitian yang dirumuskan.

Paradigma yang digunakan adalah paradigma konstruktivis dengan pendekatan deskriptif kualitatif dengan peneliti sebagai instrumen utama penelitian. Data diperoleh dari berbagai sumber seperti jurnal nasional dan internasional, buku, artikel ilmiah, surat kabar, dan dokumen pendukung lainnya.

\section{HASIL PENELITIAN}

\section{Kemerdekaan Pers di Indonesia}

Undang-undang pers di Indonesia, hadir untuk pertama kali pada ujung pemerintahan Soekarno yaitu Undang Undang Nomor 11 Tahun 1966 tentang Pers (Amrihani \& Ritonga, 2021). Tahun 1982, undang-undang tersebut direvisi oleh pemerintahan Soeharto menjadi Undang Undang Nomor 21 Tahun 1982 tentang Ketentuan Pokok Pers. Setelah Orde Baru tumbang, pers Indonesia memiliki undang-undang pers baru, yakni Undang Undang Nomor 40 Tahun 1999 tentang Pers yang masih berlaku hingga sekarang (Manan, 2012).

Terbitnya undang-undang itu, merupakan langkah maju bagi pers Indonesia, karena sejumlah aturan di masa Orde Baru yang sangat mengekang kebabasan pers sudah dihapus, seperti perusahaan pers tidak perlu lagi Surat Izin Usaha Penerbitan Pers (SIUPP); ketentuan sensor dan beredel dihapus; dan posisi Dewan Pers lepas dari anasir pemerintah. Target 
utama revisi kala itu memang ingin mendobrak belenggu pemerintah (Sukardi, 2007).

Kemerdekaan pers bukanlah semata-mata milik eksklusif para wartawan atau pemilik perusahaan pers (Sukardi, 2012). Pers merupakan lembaga sosial dan wahana komunikasi massa yang melaksanakan kegiatan jurnalistik meliputi mencari, memperoleh, memiliki, menyimpan, mengolah, dan menyampaikan informasi baik dalam bentuk tulisan, suara, gambar, suara dan gambar, serta data dan grafik maupun dalam bentuk lainnya dengan menggunakan media cetak, media elektronik, dan segala jenis saluran yang tersedia (Dewan Pers, 2021).

Pasal 4 UU Pers No 40 Tahun 1999 ayat 2 yang menyatakan, "terhadap pers nasional tidak dikenakan penyensoran, pemberedelan atau pelarangan penyiaran". Ini jelas, pers bebas dari tindakan pencegahan, pelarangan, dan atau penekanan, sehingga hak masyarakat untuk memperoleh informasi terjamin. Penyensoran, pemberedelan atau pelarangan penyiaran tidak berlaku pada media cetak dan media elektronik. Siaran yang bukan merupakan bagian dari pelaksanaan kegiatan jurnalistik diatur lebih lanjut dalam ketentuan undang-undang yang berlaku (Dewan Pers, 2020).

Undang-undang No 40 tahun 1999 tentang Pers memberikan sanksi kepada mereka yang menghalang-halangi kerja wartawan (Amri et al, 2021). Pasal 18 mengenai ketentuan pidana UU Pers ini secara tegas menyatakan, setiap orang yang secara melawan hukum dengan sengaja melakukan tindakan yang berakibat menghambat atau menghalangi pelaksanaan ketentuan Pasal 4 ayat (2) dan ayat (3) dipidana dengan pidana penjara paling lama dua tahun atau denda paling banyak lima ratus juta rupiah (Dewan Pers, 2020).

Perlindungan hukum terhadap kebebasan pers juga diperkuat dengan adanya Pasal $28 \mathrm{E}$ ayat (2) dan 28F pada perubahan kedua Undang-undang Dasar 1945. Pasal 28E (2) UUD 1945 menyatakan, "setiap orang berhak atas kebebasan meyakini kepercayaan, menyatakan pikiran dan sikap, sesuai dengan hati nuraninya." Sedangkan Pasal 28F UUD 1945 menyatakan, "setiap orang berhak untuk berkomunikasi dan memperoleh informasi untuk mengembangkan pribadi dan lingkungan sosialnya, serta berhak untuk mencari, memperoleh, memiliki, menyimpan, mengolah, dan menyampaikan informasi dengan menggunakan segala jenis saluran yang tersedia." Pasal-pasal tersebut memberikan peluang bagi pers dan setiap warga negara untuk menggunakan menyalurkan informasi, gagasan dan pendapa seluas-luasnya (Rahayu, 2007).

Undang-undang No 39 Tahun 2000 tentang Hak Asasi Manusia, terutama pada Pasal 14 ayat (1) juga menguatkan aturan hukum sebelumnya. "Setiap orang berhak untuk berkomunikasi dan memperoleh informasi yang diperoleh untuk mengembangkan pribadi dan lingkungan sosialnya" (Martini, 2014). Pers bukan sekadar penyalur opini, namun juga sebagai media komunikasi antara negara dengan masyarakat. Pers juga sebagai sumber gagasan, sarana kontrol, serta cermin tata kehidupan politik, ekonomi, sosial, dan budaya (Manan, 2012).

Kebebasan pers harus diarahkan agar dapat memberikan manfaat nyata bagi masyarakat, bukan hanya sekadar untuk membebaskan pers dan pemiliknya dari kewajiban harapan dan tuntutan masyarakat (McQuail, 2002). Kebebasan pers mencakup kebebasan eksternal dan internal. Kebebasan eksternal meliputi jaminan kemerdekaan bagi pers untuk menyiarkan dan menulis berita tanpa ada intervensi dari pihak lain. Kebebasan internal mencakup kebebasan pers dalam menulis dan menyiarkan berita tanpa ada ancaman dari dalam, dari pihak birokrasi media (Severin, W, J \& Tankard, J, W, 2005).

Dalam menjalankan fungsinya memberitakan informasi, pers nasional menurut UU No 40 Tahun 1999 tentang pers wajib: (a) menghormati norma-norma agama; (b) menghormati rasa kesusilaan masyarakat; (c) menghormati asas praduga tak bersalah; (d) mengakomodasi kepentingan semua pihak yang terkait; (e) memiliki dan menaati Kode Etik Jurnalistik (KEJ) 
(Sukardi, 2012). Keberadaan Undang-undang Pers dapat difungsikan juga sebagi kontrol sosial dan berhubungan dengan pembentukan aturan-aturan sosial. Mekanisme kontrol yang terdapat dalam suatu undang-undang adalah adanya sanksi. Dalam konteks pers, keberadaan sanksi diharapkan dapat menjadikan masyarakat patuh dan taat terhadap aturan yang berkaitan dengan pers, sehingga kebebasan pers dapat terpelihara (Rahayu, 2007).

Kemerdekaan pers yang sudah terbuka lebar, menuntut pers dan wartawan untuk mengelola ruang kemerdekaan pers agar produktif guna mengembangkan demokrasi. Namun, semua pihak yang berkepentingan dengan tumbuh kembang kemerdekaan pers harus selalu waspada. Sebab, situasi politik saat ini memunculkan kecenderungan untuk kembali merenggut kemerdekaan pers dengan melakukan kontrol terhadapnya. Tanda-tanda ke arah pemasungan pers juga sudah jelas tampak seperti ungkapan para penguasa yang menyuarakan kebebasan pers saat ini sudah kebablasan (Mutrofin \& Abar, 2002). Padahal, Undang-undang Pers dengan Pasal 4 ayat (2) merupakan Undang-undang pertama yang melindungi kemerdekaan pers sepanjang usia pers nasional sejak zaman Belanda.

\section{Kebebasan Pers di Malaysia}

Hubungan diplomatik Indonesia-Malaysia terjalin sejak 31 Agustus 1957 saat Malaysia menyatakan kemerdekaannya. Indonesia sebagai salah satu dari 14 negara yang pertama kali mengakui kemerdekaan Malaysia dan langsung menaikkan status kantor perwakilannya dari Konsulat Jenderal menjadi Kedutaan Besar Republik Indonesia dan menempatkan Mohd Razif (Alm) sebagai Duta Besar RI pertama untuk Malaysia (Kemlu, 2018). Sejuah ini hubungan Indonesia-Malaysia terjalin rukun, terutama di kalangan pemerintah. Namun, di sebagian masyarakat terkadang muncul perselisihan yang berpotensi memicu konflik bilateral. Salah satu sumber masalahnya adalah pelaporan media yang menyuarakan perasaan tidak puas terhadap beberapa isu(Mauliansyah, 2018).

Sistem pers sebuah negara dibentuk oleh keadaan politik negara tersebut (Hardt, 1997). Malaysia sebagai negara bekas jajahan Inggris, mewarisi sistem pers yang ditinggalkan Inggris. Pers pertama kali hadir di Malaysia tahun 1806 di Pulau Pinang dalam bentuk pers berbahasa Inggris yaitu Prince of Wales Island Gazette yang diperkenalkan A.B. Bone. Ia adalah seorang editor, penerbit dan pencetus pers. Hasil karyanya yang terkenal adalah The Hircarrah dan Madras Gazette (Anom, 2009).

Malaysia pada pada tahun 2021 menempati urutan ke 119 dari 180 negara dengan skor 39,47 dalam indeks kebebasan pers (RSF, 2021). Artinya, Malaysia mengalami penurunan indeks kebebasan pers dari tahun sebelumnya yakni turun 18 peringkat (Rakyat Merdeka, 2021). Sama-sama dalam posisi tidak menggembirakan dalam indeks kualitas kebebasan pers, Indonesia dan Malaysia, dua negara bertetangga ini senantiasa bersaing baik dalam bidang ekonomi, budaya, olahraga, dan hal lain (Shahab, 2018).

Indeks kebebasan pers ini mengukur tingkat kebebasan pers di dunia yang menggambarkan tahap kebebasan yang dinikmati oleh perusahaan media dan wartawan di suatu negara. Selain itu, indeks ini juga memperhitungkan usaha pemerintah dalam menghormati kebebasan berpendapat (Mauliansyah, 2018). Malaysia menjunjung tinggi nilainilai dalam kebebasan pers yang berdemokrasi karena pers memainkan peranan dalam mengelola pemerintahan dengan membentuk pendapat publik. Pemerintahan di Malaysia berasaskan demokrasi berparlemen dan raja perlembagaan. Melalui sistem ini, kuasa berada di tangan rakyat untuk memilih wakil-wakil negaranya (Anom, 2009).

Menurut laporan Reporters Without Borders, selama pandemi COVID-19, hampir 75 persen negara di dunia memblokir media dalam tingkatan tertentu. Penurunan terbesar terjadi di Malaysia karena penerapan undang-undang berita palsu yang kontroversial dan sejumlah legislasi lainnya yang membatasi, ditambah dengan penahanan, pemidanaan, dan 
penggerebekan (VOA, 2021). Pandemi COVID-19 membuat insan pers menghadapi dilema. Di satu sisi pers dibutuhkan di masa pandemi untuk mengedukasi publi sekaligus menjalankan fungsi kontrol sosial terhadap pemerintah, di sisi lain banyak insan pers yang mengalami pemutusan hubungan kerja (Deutsche Welle, 2021).

Dalam konteks Malaysia, kebebasan menyuarakan pendapat memberikan hak kepada pers nasional untuk berperan dalam menyuarakan pemberitaan yang benar dan tepat (Anom, 2009). Kebebasan berekspresi dijamin oleh Konstitusi Malaysia dalam Pasal 10 (1) (a) dan Pasal 10 (2) yang memberikan pedoman tentang kebebasan berbicara dan berekspresi, yaitu pendapat yang dikemukakan harus memperhatikan kepentingan nasional, keamanan, kepentingan dan hak istimewa pihak tertentu (Jalil, 2001).

Perdana Menteri ke-7 Malaysia, Mahathir Mohamad pernah mengatakan, kebebasan pers tidak ada artinya jika sering menyiarkan kebohongan tentang sesuatu karena terkekang oleh tujuan politik partai yang menentang pemerintah. Pers seperti ini biasanya dipengaruhi oleh pemilik, direktur, dan pihak-pihak yang bersedia menolak izin untuk menjaga ketenaran dan keuangan mereka (Othman, 2002). Hal ini juga didukung Perdana Menteri Malaysia saat ini, Ismail Sabri Yakoob yang mengatakan, pers adalah mata dan telinga, yang dapat membantu pemerintah untuk memastikan kelangsungan pembangunan untuk rakyat. Pers juga boleh membuat teguran yang bernas dan berasas untuk membantu pemerintah menyampaikan yang terbaik kepada rakyat (Maradona, 2021).

Pemerintah Malaysia juga mengumumkan persetujuan untuk melanjutkan setiap 29 Mei sebagai Hari Wartawan Nasional (Hawana) yang pertama kali diperingati pada 2018 (Setiawan, 2021). Penetapan 29 Mei merupakan tanggal edisi pertama penerbitan surat kabar Utusan Melayu, 29 Mei 1939. Hal ini juga mendapat dukungan dari para wartawan di Malaysia, salah satunya wartawan senior Malaysia, Tan Sri Johan Jaaffar yang menyatakan wartawan harus diberi ruang sebanyak-banyaknya supaya mereka dapat bekerja dengan bebas dalam menjalankan tugas di lapangan, tanpa ragu dan takut dalam menyuarakan kritikan.

Dalam peliputan berita, penulisan harus tunduk pada undang-undang seperti Konstitusi Nasional, Undang-Undang Rahasia Negara, Undang-Undang Hak Cipta 1972, Undang-Undang Penghasutan 1984, Undang-Undang Percetakan dan Penerbitan 1984, Undang-Undang Pemilihan 1954, dan juga Etika Jurnalisme. Etika yang diperkenalkan pada 20 Mei 1989, antara lain, mengatur kewajiban wartawan untuk melaporkan kebenaran dan menghormati hak publik untuk memperoleh informasi yang benar (Anom, 2009).

\section{Kebebasan Pers di Thailand}

Hubungan resmi antara Thailand dan Indonesia mulai terjalin sejak kedua negara membuka kantor perwakilannya di ibukota negara masing-masing pada 7 Maret 1950. Indonesia telah mengirimkan duta besarnya yang pertama ke Thailand pada 23 Februari 1952. Sejak itu, hubungan kedua negara berkembang pada semua tingkatan dan semua bidang, termasuk bidang penyiaran media massa, teknologi dan informasi (Kedutaan Besar RI Bangkok, 2020).

Pers di Thailand menganut sistem penyiaran Libertarian Theories, namun penekanannya adalah pada kebebasan media yang selalu dikontrol pemerintah. Meskipun kebebasannya ada pada media namun terdapat juga beberapa peraturan, pembatasan dan tindakan pemerintah dalam memublikasikan informasi sehingga pers dan masyarakat tidak memiliki kebebasan berpendapat maupun mengkritik pemerintah (Hananta et al, 2017).

Ketika junta militer di Thailand mengambil alih kekuasaan pada 22 Mei 2014, maka saat itu kebebasan pers di Thailand menjadi terbatas. Majelis Persiapan Reformasi Nasional pada 2017 mengambil keputusan terhadap Rancangan Undang-undng (RUU) tentang pengaturan 
media dan membawanya ke parlemen untuk mendapat persetujuan. RUU ini memuat pasal yang menurut 30 organisasi media di Thailand akan mematikan kemerdekaan pers di negara terebut. Pasal itu antara lain menyebutkan tentang pendirian dewan profesi media nasional yang akan diberi kuasa menghukum media yang melanggar aturan pelaksana (Rita, 2017). RUU ini dikecam oleh berbagai media (Corben, 2017).

Rancangan undang-undang ini juga mewajibkan semua awak media termasuk, pembaca berita, presenter radio, pembawa acara di televisi terdaftar. Setiap awak media mendapat lisensi dan membawa kartu identitas media. Bagi yang melanggar etika profesi akan dicopot dan dijatuhi hukuman denda. Penerbitan lisensi dan pencabutannya diputuskan oleh dewan profesi media nasional (Rita, 2017). Pasal lain yang menimbulkan perdebatan adalah dewan profesi media nasional beranggotakan 17 anggota dan empat di antaranya merupakan aparat pemerintah yang duduk sebagai sekretaris tetap dari kementerian keuangan, sosial dan ekonomi digital, budaya, dan kantor perdana menteri (Corben, 2017).

Hal ini menunjukkan kemunduran dalam sistem demokrasi termasuk dalam indek kebebasan pers. Indeks kebebasan pers Thailand menempati urutan137 dari 180 negara di dunia (RSF, 2021). Demonstrasi pro-demokrasi pada 2020 di Thailand merupakan salah satu aksi demonstrasi terbesar di tengah pandemi COVID-19 (Ahdiat, 2020). Pandemi tampaknya tidak membuat surut demonstran. Juli 2021 di tengah situasi lockdown, para demonstran melakukan demonstrasi menuntut PM Paryuth Chan-o-Cha mundur (Arunrugstichai, 2021). Demonstrasi dilakukan untuk mengkritisi pemerintahan yang dianggap otoriter.

Aksi demokrasi di Thailand yang menuntut pengunduran diri perdana menteri, pembatasan kekuasaan raja, dan amandemen konstitusi adalah sebuah keniscayaan bagi gerakan pro demokrasi, terlebih hal ini diinisiasi oleh kaum muda yang menganggap rezim yang berkuasa tidak mendukung kehidupan demokrasi, termasuk kebebasan pers (Hidriyah, 2020). Melemahnya demokrasi merupakan ancaman kebebasan pers yang akan berimplikasi kepada kualitas pemberitaan, akibat fungsi media sebagai agen konstruksi sosial masuk dalam perangkap kekuasaan (Susanto, 2013).

Tidak lama setelah meresmikan RUU pers baru, seorang jenderal militer Thailand mengungkapkan pernyataan menohok. Jenderal Thawatchai Samutsakhon mengancam akan menembak mati wartawan yang berani melancarkan kritik terhadap militer (Alim, 2017). Organisasi-organisasi media Thailand terus berjuang untuk menghentikan rancangan reformasi media yang dipandang mengenakan pembatasan terhadap kebebasan pers, termasuk pemberian izin, mendesak pemerintah militer agar meninjau Kembali rancangan undang-undang tersebut (VOA, 2017).

\section{Pembahasan}

Udang-undang Nomor 40 Tahun 1999 tentang Pers resmi diberlakukan mulai 23 September 1999 di Indonesia, hal ini menunjukkan kemerdekaan pers mulai disuarakan di seluruh wilayah Indonesia (Rahayu, 2007). Kemerdekaan pers di Indonesia merupakan salah satu wujud kedaulatan rakyat dan menjadi unsur yang sangat penting untuk menciptakan kehidupan bermasyarakat, berbangsa, dan bernegara yang demokratis sehingga kemerdekaan mengemukakan pendapat dijamin oleh Undang-undang Dasar 1945 Pasal 28 dan Undang-undang Pers No 40 Tahun 1999.

Pasal 4 ayat 2 Undang-undang Pers No 40 Tahun 1999 menyebutkan terhadap pers nasional tidak dikenakan penyensoran, pemberedelan atau pelarangan penyiaran. Artinya, penyensoran, pemberedelan, atau pelarangan penyiaran tidak berlaku pada media cetak dan media elektronik. Siaran yang bukan merupakan bagian dari pelaksanaan kegiatan jurnalistik diatur dalam ketentuan undang-undang yang berlaku. Pasal tersebut memberikan peluang bagi pers dan setiap warga untuk menggunakan kesempatan menyalurkan informasi dan 
gagasan serta pendapat seluas-luasnya.

Dalam perkembangannya, implementasi kemerdekaan pers di Indonesia yang dijamin undang undang tidak berjalan mulus, meskipun sudah berjalan lebih dari 20 tahun. Data dari Aliansi Jurnalis Independen (AJ) Indonesia mencatat, sedikitnya sudah tiga kasus kriminalisasi terhadap wartawan yang berujung pada vonis penjara dengan dasar Undang-undang tentang Informasi dan Transaksi Elektronik (UU ITE). Kasus pertama menimpa wartawan berita.news, Muhammad Asrul yang dijerat pasal pencemaran nama baik yang diatur Pasal 27 ayat 3 UU ITE (Mantalean, 2021).

Wartawan Indonesia memiliki momok terhadap undang-undang ITE. Memang pada intinya tidak ada pemberedelan terhadap perusahaan pers seperti yang terjadi pada zaman Orde Baru. Tapi, doxing ke wartawan dan kekerasan terhadap wartawan masih kerap terjadi. Jadi, yang dihantam adalah wartawan, bukan medianya yang diberedel. Selain itu, perusahaan media yang tidak mampu mengikuti perkembangan teknologi, akan mati dengan sendirinya. Disrupsi digital sangat berdampak terhadap pers. Muncul kekaburan status pers, mana karya jurnalistik dan yang bukan karya jurnalistik. Akibatnya, muncul kekaburan terhadap batas kemerdekaan pers yang perlu dilindungi dan kebebasan berekspresi di depan umum.

Mengacu pada teori pers yang ada, maka pers Indonesia pada dasarnya mengakomodir pers bebas, namun dalam praktik pelaksanaannya cenderung mengarah pada pers otoriter dengan adanya sejumlah kasus yang menghukum wartawan karena karya junalistiknya.

Kebebasan pers di Malaysia juga tidak jauh berbeda dengan Indonesia. Pers di Malaysia pada intinya tidak bebas mengkritik pemerintah. Kebebasan berkepresi di Malaysia dijamin oleh Konstitusi Malaysia dalam Pasal 10 (1) (a) dan Pasal 10 (2) (a) yang secara jelas memberikan pedoman tentang kebebasan berbicara dan berekspresi, yaitu pendapat yang dikemukakan harus memperhatikan kepentingan nasional. keamanan, kepentingan dan hak istimewa pihak tertentu.

Merujuk kepada Konstitusi Federal Malaysia Pasal 10, yang menjamin hak setiap warga negara akan kebebasan berekspresi dalam batasan tertentu, sesungguhnya tak ada kekuatan yang menghalangi masyarakat di negeri tetangga itu menyuarakan serta menerbitkan segenap pendapat dan pikirannya. Media massa Malaysia, termasuk yang berbasis internet sejatinya bebas dari sensor. Namun, pasal yang mengakui kebebasan sebagai hak yang melekat pada tiap-tiap individu itu dalam praktiknya harus takluk pada undang-undang anti penghasutan atau sedition act 1948 yang lentur, layaknya pasal karet yang ditafsirkan penguasa (Shahab, 2018).

Hal ini membuat salah satu portal berita di Malaysia (Malaysiakini.com) harus menerima sanksi denda sebesar 1,74 miliar karena lima komentar pembaca yang dianggap menghina pengadilan (Siswanto, 2021). Pada intinya pers juga boleh membuat teguran yang bernas dan berasas untuk membantu pemerintah menyampaikan yang terbaik kepada rakyat. Namun, pada kenyataannya pers tidak bebas mengkritik pemerintah.

Berdasarkan uraian tersebut, pers Malaysia dapat dikatagorikan berada dalam kuadran libertarian namun mengarah pada pers otoriter dan pemerintah mengendalikan pers. Hal yang serupa terjadi di Thailand. Pers di Thailand menganut sistem penyiaran libertarian, namun penekanannya, kebebasan media dan selalu dikontrol pemerintah. Meskipun kebebasannya ada pada media namun terdapat juga beberapa peraturan, pembatasan dan tindakan pemerintah dalam mengambil bagian mempublikasikan informasi sehingga pers dan masyarakat tidak memiliki kebebasan berpendapat dan mengkritisi pemerintah (Hananta et al, 2017). Junta militer di Thailand mengambil alih kekuasaan pada 22 Mei 2014 yang menyebabkan kebebasan pers di Thailand menjadi terbatas.

Pers di Thailand juga hampir sama dengan Malaysia yang tidak bebas mengkritik 
pemerintah. Majelis Persiapan Reformasi Nasional pada 2017 mengambil keputusan terhadap Rancangan Undang-undng (RUU) tentang pengaturan media untuk kemudian dibawa ke parlemen untuk mendapat persetujuan. Hal ini juga mengakibatkan pers di Thailand terus melakukan demonstrasi.

\section{KESIMPULAN}

Dari tiga negara yang diuraikan: Indonesia, Malaysia, dan Thailand, masing-masing negara memiliki regulasi dalam mengatur kebebasan berekspresi serta mengeluarkan pendapat. Ketiga negara tersebut memiliki aturan mengenai kemerdekaan pers yang dijamin oleh Undang-undang atau aturan lainnya, akan tetapi berbeda kadarnya dari setiap negara.

Indonesia memiliki peringkat lebih baik daripada Malaysia dan Thaliand dalam Indeks kebebasan pers. Indonesia menempati peringkat 113, Malaysia 119, dan Thailand 137. Wartawan sekarang meskipun dilindungi undang-undang dalam menjalakan profesinya, namun mereka belum sepenuhnya bebas dari ancaman jeruji besi atau denda. Wartawan diliputi rasa khawatir dalam menjalankan profesinya karena tidak bebas mengkritik perintah.

Kebebasan pers di ketiga negara tersebut membuat wartawan harus bisa "meniti buih" agar mereka terhindar dari persoalan hukum. Kebebasan pers di negara-negara tersebut idealnya harus didukung oleh pihak pemerintah agar tercipta kehidupan demokrasi yang dinamis. Dengan adanya kebebasan pers yang tidak mendua, wartawan dapat melaksanakan tugasnya dengan aman, dan leluasa memberitakan fakta-fakta atas suatu peristiwa yang terjadi.

\section{DAFTAR PUSTAKA}

Ahdiat, A. (2020, November 19). PM Thailand ancam gunakan seluruh aturan hukum untuk jerat demonstran. Antaranews.com. Diakses dari https://www.antaranews.com/berita/1849284/pm-thailand-ancam-gunakan-seluruhaturan-hukum-untuk-jerat-demonstran.

Alim, M. (2017, Mei 3). Kebebasan pers di Thailand dikebiri, Jenderal ancam bunuh jurnalis. Jurnas.com. Diakases dari https://www.jurnas.com/artikel/15628/Kebebasan-Pers-diThailand-Dikebiri-Jenderal-Ancam-Bunuh-Jurnalis/.

Amri et al. (2021). Pro dan kontra Undang-undang nomor 40 tahun 1999 tentang pers sebagai lex specialis. Jurnal IImu Komunikasi, 7(1), 87-94.

Amrihani, H, A., Ritonga, R. (2021). Freedom of the press regulations in Indonesia and Sweden: Limited but Free. Jurnal Ikatan Sarjana Komunikasi Indonesia, 6(2), 353361.doi: 10.250008/jkiski.v6i2.609

Anom, E. (2009). Kebebasan pers: Perbandingan antara Malaysia dan Indonesia. Jurnal Komunikologi, 6(2), 95-104.

Arunrugstichai, A. (2021, Juli 18). Tuntut PM mundur, warga Thailand demo di kala lockdown. Detik.com. Diakses dari https://news.detik.com/foto-news/d-5648093/tuntut-pmmundur-warga-thailand-demo-di-kala-lockdown/3.

Baron, S, D., Davis, D, K. (2012). Mass communication theory, Chicago: Wadsworth.

BSSN. (2016). Perubahan kedua Undang-undang Dasar Negara Republik Indonesia. Diakses dari content/uploads/2016/01/UUD1945PerubahanKedua.pdf.

Corben, R. (2017, Januari 31). Organisasi media Thailand desak amandemen RUU reformasi 
media. Voaindonesia.com. Diakses dari https://www.voaindonesia.com/a/mediathailand-desak-amandemen-ruu-reformasi-media-/3699134.html.

Deutsche Welle. (2021, Februari 9). Hari pers nasional: Pandemi Corona memperburuk kebebasan pers. Dw.com. diakses dari https://www.dw.com/id/pandemi-coronamemperburuk-kebebasan-pers/a-56506517.

Dewan Pers. (2020). Buku saku wartawan, Jakarta: Dewan Pers.

Dewan Pers. (2021, Oktober 18). Undang-undang No 40 tahun 1999. Dewanpers.or.id. Diakses dari https://dewanpers.or.id/kebijakan/peraturan.

Hananta et al. (2017). Peran militer dan sipil dalam politik dan pemerintahan di Thailand, Lampung: Universitas Lampung.

Hardt, H. (1997). Social theory of the press; Early German and American Perspective. Beverly Hilss: Sage Publications.

Hidriyah, S. (2020). Demontrasi pro-demokrasi di Thailand. Kajian Singkat Terhadap Isu Aktual dan Strategis, 12(20), 7-12.

Hutagalung, I. (2013). Dinamika sistem pers di Indonesia. Jurnal Interkasi, 2(2), 53-60.

Idrus, P. (2020, Oktober 20). Organisasi pers Thailand minta pemerintah tak sensor media. Aa.com.tr. Diakses dari https://www.aa.com.tr/id/regional/organisasi-pers-thailandminta-pemerintah-tak-sensor-media/2012382.

Jalil, F. (2001). Kebebasan dan jenayah dalam berkarya, Kuala Lumpur: Dewan Sastera.

Kedutaan Besar Republik Indonesia Bangkok. (2020). Selayang pandang hubungan bilateral Indonesia dan Thailand, Bangkok: Kedutaan Besar Republik Indonesia Bangkok.

Kemlu. (2018). Konsulat Jenderal Republik Indonesia di Penang Malaysia. Kemlu.go.id. Diakses dari https://kemlu.go.id/penang/id/read/malaysia/950/etc-menu.

Lesmana, T. (2005). Kebebasan pers dilihat dari perspektif konflik, antara kebebasan dan tertib sosial. Jurnal Ilmu Komunikasi, 2(1), 1-14.

Manan, B. (2012). Politik publik pers, Jakarta: Dewan Pers.

Mantalean, V. (2021, Desember 29). Anggap UU ITE momok media, AJl catat 3 jurnalis dipenjara sepanjang 2021. Kompas.coom. Diakses dari https://nasional.kompas.com/read/2021/12/29/21061491/anggap-uu-ite-momokmedia-aji-catat-3-jurnalis-dipenjara-sepanjang-2021?page=all.

Maradona, S. (2021, Desember 1). ISWAMI sambut positif sikap PM Malaysia. Republika.co.id. Diakses dari https://www.republika.co.id/berita/r3fxgl475/network.

Martini, R. (2014). Analisis peran dan fungsi pers sebelum dan sesudah reformasi politik di Indonesia. Jurnal IImu Sosial, 13(2), 1-9.

Marzuki, P, M. (2005). Penelitian Hukum. Jakarta: Prenada Media.

Mauliansyah, F. (2018). Studi perbandingan konflik pers Indonesia dan pers Malaysia dalam konteks nationality of press dan neighbor's press. Jurnal Universitas Teuku Umar, 3(1), 1-13.doi: $10.35308 /$ source.v3i1.626

McQuail, D. (2002). Mass communication theory, London: Sage Publications.

Mutrofin., Abar, A, Z. (2002). Kemerdekaan dan profesionalisme pers di Indonesia. Makalah Diklat Jurnalistik Mahasiswa Jurusan Dakwah Sekolah Tinggi Agama Islam Negeri 
Jember.

Nursalikah, A. (2021, Februari 19). Situs Malaysiakini dedenda Rp 1,7 miliar. Republica.co.id. Diakses dari https://www.republika.co.id/berita/qorx9q366/situs-malaysiakinididenda-rp-17-miliar.

Othman, M. (2002). Erti kebebasan pers persekitaran yang membimbangkan. Sasaran: Kuala Lumpur.

Poti, J. (2011). Demokratisasi media massa dalam prinsip kebebasan. Jurnal Ilmu Politik dan Ilmu Pemerintahan, 1(1), 17-29.

Purwanto, A. (2005). Kebebasna pers dalam perspektif hak asasi manusia dan asas praduga tak bersalah: studi kasus majalah Tempo dan surat kabar Jawa Pos, Jakarta: Tesis Universitas Indonesia.

Rahayu, M, I, F. (2007). Kebebasan pers dalam konteks KUHP pidana: Menyoal Undangundang sebagai fungsi komunikasi. Jurnal Mediator, 8(1), 125-130.

Rakyat Merdeka. (2021, Mei 6). Indeks kebebasan pers RI kalah dari Timor Leste. Rm.id. Dikases dari https://rm.id/baca-berita/internasional/74967/indeks-kebebasan-pers-rikalah-dari-timor-leste.

Reporters Without Borders. (2021). 2021 world press freedom index. Diakses dari https://rsf.org/en/malaysia.

Rita, M. (2017, Februari 2). RUU ini diloloskan, kemerdekaan pers di Thailand temui ajal. Tempo.co. Diakses dari https://dunia.tempo.co/read/842225/ruu-ini-diloloskankemerdekaan-pers-thailand-temui-ajal.

Rizal, J. (2020, Oktober 19). Aksi masih terus terjadi, Pemerintah Thailand akan investigasi media. Kompas.com. Diakses dari https://www.kompas.com/tren/read/2020/10/19/165100765/aksi-masih-terusterjadi-pemerintah-thailand-akan-investigasi-media?page=all.

Setiawan, A. (2021, November 30). Malaysia setujui 29 Mei sebagai hari wartawan nasional. Antaramews.com. Diakases dari https://www.antaranews.com/berita/2556493/malaysia-setujui-29-mei-sebagai-hariwartawan-nasional.

Severin, W, J \& Tankard, J, W. (2005). Teori komunikasi, Jakarta: Kencana.

Shahab, I. (2018, Februari 14). Malaysia dan kebebasan pers. Tempo.co. Diakses dari https://hukum.tempo.co/read/1060537/malaysia-dan-kebebasan-pers.

Siswanto. (2021, Februari 20). Komentar pembaca dianggap menghina, Malaysiakini dedenda 1,74 m. Suara.com. Diakses dari https://www.suara.com/news/2021/02/20/161459/komentar-pembaca-dianggapmenghina-malaysiakini-didenda-174-m.

Sukardi, W, A. (2007). Keutamaan di balik kontroversi undang-undang pers, Jakarta: Dewan Pers.

Sukardi, W, A. (2012). Kajian tuntas 350 tanya jawab UU Pers dan kode etik jurnalistik, Jakarta: Dewan Pers.

Susanto, E, H. (2013). Media massa, pemerintah dan pemilik modal. Jurnal Komunikasi, 1(6), 477-484. 
Suwardi, H. (1993). Peranan pers dalam politik Indonesia: Suatu studi komunikasi politik terhadap liputan berita kampanye pemilu 1987, Jakarta: Pustaka SInar Harapan.

Triyono, D. (2013). The four press media theories: Authorianisme media theory, libertarianism media theory, social responsibility media theory, and totalitarian media theory. Jurnal Pengembangan Humaniora, 13(3), 194-201.

VOA. (2021, Februari 19). Situs berita Malaysia dedenda di tengah kekhawatiran kebebasan pers. Voaindonesia.com. Diakses dari https://www.voaindonesia.com/a/situs-beritamalaysia-didenda-di-tengah-kekhawatiran-kebebasan-pers/5784617.html.

VOA. (2021, April 24). Wartawan tanpa tapal batas: Kebebasan pers secara global menurun. Voaindonesia.com. Diakses dari https://www.voaindonesia.com/a/wartawan-tanpatapal-batas-kebebasan-pers-secara-global-menurun/5864875.html.

Waluyo, D. (2018). Makna jurnalisme dalam era digital: Suatu peluang dan transformasi. Jurnal Media dan Komunikasi, 1(1), 33-42. 